\section{State of the world: IISS reports}

"Almost medieval turbulence under a nuclear umbrella", is how the International Institute of Strategic Studies' (IISS) annual report for 1973 describes the military and political scene last year (IISS, 18 Adam Street, London WC2). In a year marked by the withdrawal of the United States from Vietnam, a commitment between President Nixon and Secretary Brezhnev to negotiate a SALT II agreement, the downthrow of President Allende, the Middle East War, the appearance of the oil weapon and ominous creakings in unity not only within Europe but with the United States, the epithet is well deserved.

The greatest strategic development was undoubtedly the use of oil as a weapon which "opened up prospects of entirely new political balances". The quadrupling within a year of oil prices led to Dr Kissinger's proposal for an Energy Action Group, but there were many defections from the united front that was hoped for as western Europe and Japan pursued bilateral deals with oil producers; the ingredients of many of these included arms sales. Already in the eighteen months prior to the October war nearly $\$ 5,000$ million worth of arms deals had been made with Persian Gulf states-mainly Iran and Saudi Arabia. Iran, in particular, sees threats both internal and external-indeed there are potential dangers on all sides except from Pakistan. The IISS finds it difficult to predict the military future in the Gulf, so complex is the scene. On the one hand armed-to-the-teeth means bloody conflict; on the other, the strength of Iran and Saudi Arabia means stability. A familiar problem for strategists.

The prospects for SALT II are gloomy, as United States-Soviet tensions grew in 1973. There are some sticky problems for negotiators. In August the United States announced MIRV tests had begun in the Soviet Union thus starting the process by which American qualitative superiority though with numerical inferiority in missiles is eroded. And ultimately the accuracies of land-based missiles are so great that if the number of such missiles possessed by one side exceeds that of the other, first strike by the bigger force against the other side's launchers as good as ensures missile victory. The United States is believed to be aiming in SALT II for some sort of numerical equality with limited freedom to $\mathrm{mix}$ missiles. This, of course, leaves the American bomber superiority untouched. The Soviet Union is said to have responded that numerical equality would require the dismantling of American Forward-based Systems such

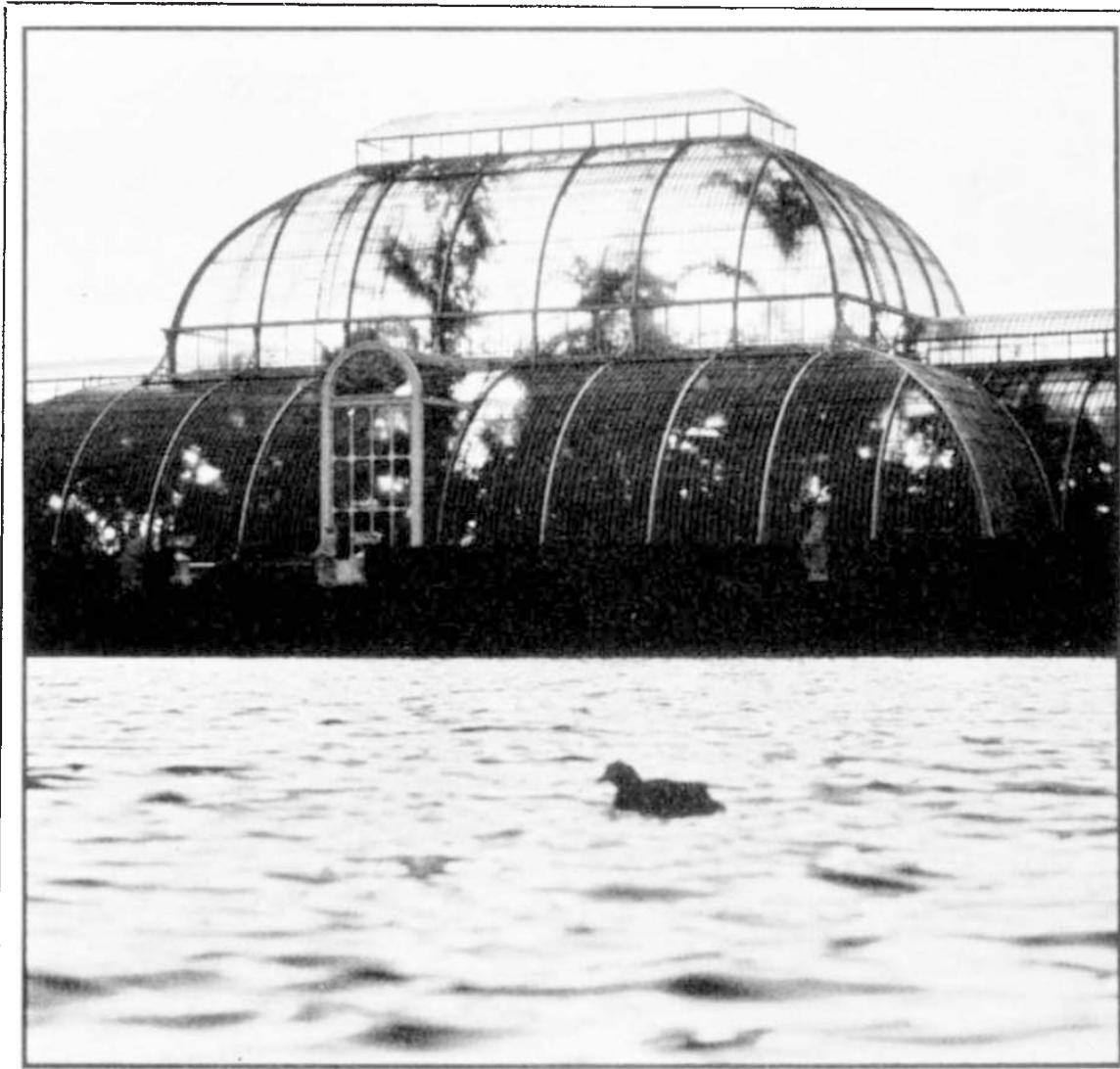

VISITORS had an opportunity to see the other side of Kew when the Royal Botanic Gardens held its open days recently, and the laboratories, library disappearance of individual species is and herbarium were open to the the destruction of large areas of public. The Director, Professor J. natural habitat by man's expansion. Heslop-Harrison, stressed the import- Professor Heslop-Harrison said that ance of the gardens as a repository for although the general public is now living wild plant species. The plant sympathetic to the idea of wildlife kingdom is in retreat, he said, and conservation the less glamorous conabout a tenth of known angiosperm cept of vegetation conservation is species are in grave danger. By the end difficult to communicate, although of of the century half of these would prime importance. If you want to save almost certainly be extinct. As part the tiger, he said, first save the teak of a worldwide effort to conserve this forests in which it lives. In the gardens fast disappearing genetic resource, a themselves, the Temperate House, seed bank has already been set up designed by Decimus Burton and built which he hopes will eventually form between 1860 and the 1890 s is now the core of a national seed bank com- being completely restored and renoparable with those in Leningrad and vated as was the Palm House some Colorado. Equally as disastrous as the years ago.

as European submarine bases. She also proposed a prohibition on further research and development of bombers, cruise missiles, penetration aids and airto-surface nuclear missiles. "Outrageous", said the United States.

The problem for the 1990s is the submarines, the institute believes. Much will hang on breakthroughs, if any, in anti-submarine warfare technology, and there are various actions that could be taken to ensure submarine invulnerability. Continuous tracking of submarines could be prohibited, as could large scale sonar installations. Sanctuaries could be provided for submarines. This is the stuff of arms control in the late 1970s and the sooner it is widely discussed the better.

Will the Soviet Union attack China in 1974? The IISS sees this as a serious option for Soviet policy, but concludes that the days are over when a surgical strike against Chinese nuclear facilities would have destroyed the country's weapons programme. Further, China now has more allies, and is capable of inflicting some damage on Soviet cities.

The troubles of Angola, Mozambique, Rhodesia, Namibia and South Africa with insurgents are given four pages, the Northern Ireland troubles not a word. A pity; a brief analysis in the IISS's lucid style would have helped. 